ISSN: $2623-0852$

\title{
PENGARUH TEMAN SEBAYA, ORANG TUA, DAN GURU TERHADAP MASALAH BELAJAR ANAK SUPERIOR
}

\author{
K. Yunanda Luxiana Parwata, A. A. I. Agung Rai Sudiatmika, N. L. Pande Latria Devi
}

\author{
Program Studi S1 Pendidikan IPA \\ Universitas Pendidikan Ganesha \\ Singaraja, Indonesia
}

e-mail: \{luxiana.parwata, rai.sudiatmika, latria.devi\}.@undiksha.ac.id

\begin{abstract}
ABSTRAK
Penelitian ini bertujuan untuk mendeskripsikan pengaruh teman sebaya, orang tua, dan guru terhadap masalah belajar anak superior. Subjek penelitian adalah anak superior di SMPN 4 Singaraja yang dipilih menggunakan tehnik purposive sampling $(\mathrm{n}=7$ orang). Data pengaruh teman sebaya, orang tua, dan guru terhadap masalah belajar anak superior digali selama 60 hari melalui angket dan wawancara. Data penelitian dianalisis secara deskriptif kualitatif mengikuti tahapan analisis data Bogman yang terdiri dari 3 tahapan, yakni: Deskripsi, Reduksi, dan Seleksi. Berdasarkan hasil penelitian, rata-rata hubungan anak superior dengan teman sebaya, hubungan anak dengan orang tua, dan hubungan anak dengan guru, memberi pengaruh positif terhadap masalah belajar anak (anakteman sebaya $75.87 \%$, anak-orang tua $62,91 \%$, anak-guru $74,60 \%$ ).
\end{abstract}

Kata kunci: masalah belajar, teman sebaya, orang tua, guru, superior

\begin{abstract}
This study aims to describe the influence of peers, parents, and teachers to superior child learning problems. The research subjects were the superior children in SMPN 4 Singaraja who were selected using purposive sampling technique ( $\mathrm{n}=7$ people). Data on the influence of peers, parents, and teachers on superior child learning problems were excavated for 60 days through questionnaires and interviews. The research data was analyzed descriptively qualitative following Bogman data analysis step which consist of 3 stages, namely: Description, Reduction, and Selection. Based on the research result, the average of superior child relationship with peers, the relationship of children with parents, and the relationship of children with the teacher, give positive influence to the problem of children learning (children-peers $75.87 \%$, children-parents $62.91 \%$, children-teachers $74.60 \%$ ).
\end{abstract}

Keywords: learning problems, peers, parents, teachers, superior

\section{PENDAHULUAN}

Sistem Pendidikan Nasional di Indonesia menurut UU no. 20 Tahun 2003 bertujuan mencerdaskan kehidupan bangsa dan mengembangkan manusia Indonesia seutuhnya, yaitu manusia yang beriman dan bertaqwa kepada Tuhan Yang Maha Esa dan berbudi pekerti luhur, memiliki pengetahuan dan keterampilan, kesehatan jasmani dan rohani, kepribadian yang mantap, serta tangung jawab kemasyarakatan dan kebangsaan. Berbagai upaya telah dilakukan pemerintah dalam rangka mewujudkan tatanan pendidikan yang ideal sebagaimana diatur dalam undang-undang. Hal ini tampak dari perbaikan-perbaikan yang dilakukan pada 
kurikulum pendidikan nasional. Fakta di lapangan, hasil studi PISA (Program for International Student Assessment) tahun 2015 menunjukkan Indonesia baru bisa menduduki peringkat 69 dari 76 negara.

Peraturan perundang-undangan terkait sistem pendidikan nasional pun dibuat sebagai upaya meningkatkan kualitas pendidikan nasional. Salah satu upaya untuk meningkatkan kualitas pendidikan nasional adalah membatasi jumlah peserta didik dalam satu rombongan belajar. Pembatasan jumlah peserta didik dilakukan sebagai upaya agar kebutuhan sarana dan prasarana pendididkan peserta didik dapat terpenuhi. Jumlah peserta didik yang ideal berdasarkan Permendikbud Nomor 17 Tahun 2017 untuk jenjang SMP di dalam satu kelas ialah 20 s.d. 32 peserta didik. Kenyataannya berdasarkan hasil observasi yang dilakukan di SMPN 4 Singaraja, diketahui bahwa terdapat 37 s.d. 41 peserta didik dalam 1 rombongan belajar. Banyaknya peserta didik dalam 1 kelas menyebabkan kebutuhan masing-masing anak tidak terpenuhi yang menyebabkan anak mengalami kesulitan dalam memahami dan menyerap pembelajaran yang disampaikan di kelas.

Kemampuan anak untuk memahami dan menyerap pelajaran berbeda-beda tingkatannya (Uno, 2008). Oleh karenanya setiap anak, terutama anak berkebutuhan khusus, memerlukan perhatian yang berbeda. Anak berkebutuhan khusus adalah anak-anak yang menunjukkan karakteristik berbeda dari anak-anak sebayanya. Anak berkebutuhan khusus mengacu pada anak cerdas berbakat isimewa dan anak yang terlahir dengan kekurangan baik secara fisik mapupun mental (Thompson, 2010).

Anak cerdas berbakat istimewa dapat diketahui dengan melakukan tes kecerdasan. Terdapat berbagai jenis alat ukur kecerdasan yang berkembang. Alat ukur yang umum digunakan untuk mengukur kecerdasan anak adalah Tes IQ (Intelligence Quotient) tipe WISC yang menurut Santrock (2008) dapat memprediksi kecerdasan anak. Triconta merupakan salah satu lembaga bimbingan dan konsultasi psikologis di Indonesia yang menggunakan WISC sebagai dasar melakukan tes IQ. WISC (Wechsler Intelligence Scale for Children) merupakan tes IQ yang diperkenalkan oleh David Wechsler yang diperuntukkan untuk anak rentang usia 6-16 tahun (Gregory, 2010). Terdapat dua kategori yang diujikan dalam tes ini, yakni kemampuan verbal dan motorik. Menurut Gregory (2010) kemampuan verbal dan motorik merupakan dasar yang harus dimiliki seseorang untuk dapat mengembangkan diri.

Terdapat 10 tingkatan IQ yang dikembangkan oleh Wechsler (Sukardi, 1997). Diantara semua tingkatan yang ada, anak-anak yang terlahir dengan potensi intelektual cerdas dan berbakat istimewa atau biasa disebut superior mulai menjadi sorotan masyarakat. Menurut Zubaidi (2007) superior adalah istilah untuk anakanak yang memiliki tingkatan inteligensi (IQ) 120-139. Anak-anak ini dianugerahi kecerdasan diatas normal yang memungkinkan mereka berkembang pesat melebihi anak sebayanya (Oktaviai, 2014). Ditinjau dari potensi intelektual yang dimiliki, tentu prestasi anak superior akan berada diatas anak lain sebayanya.

Kenyataannya, tidak semua anak yang lahir membawa anugerah ini bisa mengembangkan potensinya dengan baik. Siswa berbakat beresiko tinggi mengalami masalah belajar (Blaas, 2014). Masalah belajar dalam konteks ini mengarah pada ketidakmampuan anak untuk menampilkan potensi akademik yang dimilikinya. Menurut Oktaviani dan widayat (2013) anak superior memiliki potensi intelektual yang sangat besar sehingga mereka dapat mengerti materi pembelajaran, namun karena alasan terentu mereka tidak dapat mereka menampilkan hasil belajar sesuai potensinya. Hal tersebut dapat terjadi karena ketidak siapan mental anak untuk mengeksplorasi bakat yang dimilikinya. Ada pihak-pihak yang beranggapan bahwa anak yang memiliki bakat diatas rata-rata tidak perlu dibimbing karena mereka sudah mampu belajar secara mandiri (Song, 2014). Kenyataannya, setiap anak butuh bimbingan untuk dapat berkembang kearah yang baik. Oktaviani dan widayat (2013) mengungkapkan bahwa anak berbakat 
memerlukan perhatian khusus dan metode penanganan yang berbeda dari anak-anak lainnya. Apabila tidak mendapat bimbingan, sangat besar kemungkinan anak tersebut mengalami depresi akibat tidak dapat mengendalikan pikirannya sendiri dan merasa tidak mendapat dukungan. Tidak menutup kemungkinan anak tersebut malah berkembang ke arah yang negatif.

Berbeda dengan anak yang terlahir dengan kekurangan, anak superior jarang di jumpai di Sekolah Luar Biasa (SLB). Mereka kerap dijumpai pada sekolah umum negeri ataupun swasta. Keberadaan sekolah khusus untuk anak-anak superior pun masih belum tercatat secara pasti jumlahnya dalam berita statistik yang dikeluarkan oleh Badan Pusat Statistika Republik indonesia (Badan Pusat Statistik, 2017). Hal ini menunjukkan bahwa anak superior masih belum mendapat perhatian penuh walaupun UU No. 20 tahun 2003 tentang Sistem Pendidikan Nasional, pasal 5 ayat 4 menyatakan, "Warga negara yang memiliki potensi kecerdasan dan bakat istimewa berhak memperoleh pendidikan khusus". Berdasarkan hasil observasi awal, diketahui terdapat 7 anak superior yang bersekolah di SMPN 4 Singaraja.

Kasus - kasus adanya anak superior yang tidak dapat berkembang dengan maksimal mulai banyak bermunculan di berbagai satuan pendidikan. Penelitian yang dilakukan oleh Song (2014) menunjukkan bahwa terdapat anak dengan kecerdasan diatas rata-rata yang mengalami kesulitan belajar karena penanganan yang tidak tepat. Penanganan yang tidak tepat disebabkan karena kurangnya pengetahuan mengenai masalah belajar pada anak superior. Masalah belajar dapat disebabkan oleh beberapa hal. Slameto (2010) mengungkapkan keberhasilan belajar siswa dipengaruhi oleh faktor internal dan faktor eksternal. Rifa'i dan Anni (2012) menggolongkan faktor internal mencakup kondisi fisik, kondisi psikis, dan kondisi sosial, sedangkan kondisi eksternal meliputi variasi dan tingkat kesulitan materi belajar (stimulus) yang dipelajari, tempat belajar, iklim, suasana lingkungan, dan budaya belajar masyarakat akan mempengaruhi kesiapan, proses, dan hasil belajar, dan hubungan anak dengan lingkungannya.

Hubungan anak dengan lingkungannya berupa hubungan anak dengan teman sebaya, anak dengan orang tua, dan anak dengan guru merupakan faktor penting yang mempengaruhi masalah belajar anak. Pendapat ini didukung berbagai penelitian yang mengungkapkan adanya pengaruh prestasi belajar yang disebabkan oleh hubungan anak dengan teman, anak dengan orang tua, dan anak dengan guru. Hubungan anak dapat memberi pengaruh positif dan negatif terhadap masalah belajar anak. Hubungan positif yang dimaksud adalah hubungan yang dapat memotivasi anak dalam belajar, sedangkan hubungan negatif adalah hubungan yang membuat anak tidak termotivasi belajar.

Hubungan anak dengan teman sebaya memberi pengaruh terhadap prestasi anak (Ernawati, 2014; Kharisma dan Lutifah, 2015; Khumaero, 2017; Kusuma dan Muhsin, 2016). Pengaruh tersebut terjadi karena dalam keseharian anak banyak menghabiskan waktu dengan teman dan cenderung merasa ingin diterima serta diperhatikan oleh teman sebayanya sehingga ia akan berusaha untuk berbaur. Kelompok teman sebaya terdiri dari orangorang yang memiliki persamaan usianya, kelompok monoseksual, atau kelompok yang memiliki kesamaan status (Tirtaraharja dan Sulo, 2010). Melalui hubungan dengan teman sebaya, anak dapat menilai status dirinya sama, berbeda, diterima, atau ditolak oleh lingkunganya. Hal ini tidak bisa dilakukan anak didalam keluarga karena orang tua atau saudara anak memiliki tingkatan usia dan status yang berbeda (Santrock, 2009).

Semakin baik (positif) pergaulan anak dengan teman sebayanya, maka semakin baik pula prestasi belajar yang didapat anak, sebaliknya apabila semakin rendah (negatif) pergaulan siswa dengan teman sebayanya, maka semakin rendah pula prestasi belajar yang didapat anak (Khumaero. 2017). Hasil ini didukung penelitian Mujiastuti (2015) yang mengungkapkan bahwa anak yang memiliki persahabatan yang baik memiliki memiliki 
prestasi yang lebih baik dari pada anakanak yang tidak memiliki sahabat.

Selain teman sebaya, hubungan anak dengan orang tua memberikan berpengaruh terhadap masalah belajar yang dialami anak (Bangun, 2008; Situmorang dan Latifah, 2014). Hubungan positif anak dengan orang tua dapat berupa: menyediakan fasilitas belajar anak, mengawasi kegiatan belajar anak, menanyakan kegiatan dan hasil belajar anaknya, memberikan penghargaan terhadap prestasi anak, mengawasi penggunaan waktu belajar anak, serta keinginan orang tua untuk bisa lebih dekat dan mengenal wali kelas atau para guru yang mengajar anaknya (Bangun, 2008).

Hubungan negatif antara anak dengan orang tua berupa pengucapan katak-kata negatif, kurang perhatian, maupun kurang dukungan dari orang tua terhadap prestasi anak berdampak pada kurangnya motivasi anak dalam belajar. Kurangnya dukungan dari orang tua menyebabkan anak memiliki konsep diri dan kepercayaan diri yang rendah. Anak menganggap bahwa belajarnya tidak didukung oleh orang tua sehingga anak akan merasa sia-sia dalam belajar. Bangun (2008) yang menyebutkan orang tua yang tidak memperhatikan pendidikan anaknya atau tidak peduli dengan kegiatan belajar anaknya, mengakibatkan anak tidak termotivasi dalam belajar.

Hubungan anak dengan guru menjadi salah satu komponen penting yang juga harus diperhatikan karena guru merupakan pembimbing utama anak dalam belajar di sekolah. Guru memberi pengaruh terhadap hasil belajar anak (Angganing, 2011; Aritonag, 2006; Khumaero, 2017). Cara mengajar guru, karakter guru dan anak, dan fasilitas belajar yang digunakan merupakan faktor-faktor yang harus diperhatikan guru dalam mengajar (Aritonag; 2006).

Berdasarkan uraian diatas, penelit ingin mengkaji bagaimana pengaruh teman sebaya, orang tua, dan guru terhadap masalah belajar anak superior.

\section{METODE PENELITIAN}

Penelitian ini merupakan studi kasus yang dirancang secara kualitatif deskriptif. Subjek penelitian ini adalah anak superior di SMPN 4 Singaraja yang dipilih menggunakan tehnik purposive sampling $(n=7$ orang). Data pengaruh teman sebaya, orang tua, dan guru terhadap masalah belajar anak superior digali melalui angket dan wawancara. Penelitian berlangsung selama 60 hari yang berlokasi di SMPN 4 Singaraja dan masing-masing rumah tinggal subjek. Data yang diperoleh dianalisis secara deskriptif kualitatif mengikuti tahapan analisis data Bogman yang terdiri dari 3 tahapan, yakni: Deskripsi, Reduksi, dan Seleksi.

Pada tahap deskripsi, peneliti memaparkan secara rinci data yang diperoleh melalui wawancara dan angket.

Reduksi data berarti merangkum atau pencatatan, memilih hal-hal yang pokok, memfokuskan pada hal-hal yang penting, dan membuang yang tidak diperlukan. Pada tahap Reduksi, peneliti memfokuskan data yang diperoleh dan mengklasifikasi data sesuai dengan indikator penelitian.

Seleksi yaitu penguraian fokus menjadi komponen yang lebih spesifik dan penyusunan pola data. Peneliti menyusun data-data yang diperoleh menjadi pola dan melakukan analasis mendalam terhadap data guna menjawab permasalahan penelitian. Hasil dari seleksi data ini kemudian akan dirangkum menjadi suatu kesimpulan.

\section{HASIL DAN PEMBAHASAN}

Berdasarkan Tabel 1, diketahui ratarata hubungan anak superior dengan teman sebaya, hubungan anak dengan orang tua, dan hubungan anak dengan guru, memberi pengaruh positif terhadap masalah belajar anak (anak-teman sebaya $75.87 \%$, anakorang tua $62,91 \%$, anak-guru $74,60 \%$ ). 
Tabel 1. Hubungan Anak Superior dengan Teman Sebaya, Orang Tua, dan Guru

\begin{tabular}{|c|c|c|c|c|c|c|c|c|c|}
\hline \multirow{3}{*}{ Subjek } & \multicolumn{9}{|c|}{ HUBUNGAN ANAK DENGAN } \\
\hline & \multicolumn{3}{|c|}{ Teman } & \multicolumn{3}{|c|}{ Orang Tua } & \multicolumn{3}{|c|}{ Guru } \\
\hline & $\mathbf{S}$ & I (\%) & $\mathbf{K}$ & $\mathbf{S}$ & I (\%) & $\mathbf{K}$ & $\mathbf{S}$ & I (\%) & $\mathbf{K}$ \\
\hline $\mathbf{A}$ & 26 & 57.78 & S & 23 & 73.33 & $\mathrm{P}$ & 33 & 73.33 & $\mathrm{P}$ \\
\hline B & 36 & 77.78 & $P$ & 25 & 83.33 & $\mathrm{SP}$ & 33 & 73.33 & $\mathrm{P}$ \\
\hline $\mathbf{C}$ & 32 & 71.11 & $P$ & 16 & 53.33 & $\mathrm{~S}$ & 29 & 64.44 & $\mathrm{P}$ \\
\hline D & 32 & 77.78 & $P$ & 17 & 59.33 & S & 36 & 80.00 & SP \\
\hline $\mathbf{E}$ & 39 & 86.67 & SP & 28 & 93.33 & SP & 34 & 75.56 & $P$ \\
\hline $\mathbf{F}$ & 31 & 75.56 & $P$ & 22 & 77.78 & $P$ & 35 & 77.78 & $\mathrm{P}$ \\
\hline $\mathbf{G}$ & 38 & 84.44 & SP & 21 & 73.33 & $P$ & 35 & 77.78 & $P$ \\
\hline RATA-R & & 75.87 & $P$ & & 62.91 & $P$ & & 74.60 & $P$ \\
\hline
\end{tabular}

Keterangan:

$\mathrm{S}=$ Skor, I=Indeks, K=Katagori, S=Sedang P=Positif, SP=Sangat Positif

Hubungan Anak dengan Teman Sebaya

Hubungan anak dengan teman memiliki indeks yang lebih tinggi dari hubungan anak dengan orang tua dan hubungan anak dengan guru. Rata-rata anak superior menganggap hubungan dengan teman berpengaruh positif terhadap masalah belajar yang dialaminya. Masing-masing anak superior memiliki teman yang mendukung proses belajarnya. Hasil penelitian ini sejalan dengan berbagai penelitian yang mengungkapkan bahwa teman sebaya memang sangat mempengaruhi pola perilaku anak (Ernawati, dkk, 2014; Kharisma dan Lutifah, 2015; Khumaero. 2017; Kusuma dan Muhsin, 2016; Mujiastuti dan Ilyasir, 2015; Santrock, 2008). Pengaruh tersebut terjadi karena dalam keseharian anak banyak menghabiskan waktu dengan temantemannya (Karisma dan Latifah, 2015). Dengan demikian maka akan tercipta persepsi yang sama. Selain itu, anak cenderung merasa ingin diterima dan diperhatikan oleh teman sebayanya sehingga ia akan berusa untuk berbaur. Oleh karenanya sangat penting bagi anak untuk berada pada lingkungan yang mendukungnya belajar.

Apabila dianalisis secara individu, 2 dari $7 \quad(28,6 \%)$ anak superior menganggap hubungan dengan teman berpengaruh sangat positif terhadap masalah belajar yang dialaminya. Kedua anak tersebut mengaku semakin termotivasi dalam belajar ketika melihat teman yang memperoleh nilai yang lebih tinggi. Masingmasing anak mengaku memiliki teman yang mendukung mereka dalam belajar. Mereka mengaku memiliki kelompok belajar untuk berdiskusi mengenai materi pembelajaran dan tugas-tugas sekolah. Mereka merasa nyaman untuk berdiskusi karena temantemannya memberi tanggapan positif dan terbuka terhadap pendapat mereka. Hasil ini senada dengan penelitian Khumaero (2017) yang mengungkapkan bahwa semakin baik (positif) pergaulan anak dengan teman sebayanya, maka semakin baik pula prestasi belajar yang didapat anak.

4 dari 7 (57,1\%) anak superior menganggap hubungan dengan teman berpengaruh positif terhadap masalah belajar yang dialami. Keempat anak tersebut mengaku memiliki kelompok pertemanan dan menghabiskan banyak waktu di sekolah dan di luar sekolah dengan berkumpul bersama kelompoknya pertemanannya. Mereka sering menghabiskan waktu untuk belajar dan bermain bersama. Anak merasa nyaman dalam berteman karena memiliki kesamaan hobi atau idola. Keempat anak superior dan temannya saling mengingatkan satu sama lain mengenai tugas dan berbagi 
pengetahuan mengenai materi yang mereka pahami. Ini merupakan hubungan positif anak dengan teman. Hasil ini didukung penelitian Mujiastuti dan Ilyasir (2015) bahwa kegiatan beajar bersama, diskusi, dan tutor sebaya, efektif untuk meningkatkan prestasi anak.

1 dari 7 (14,3\%) anak superior menganggap hubungan dengan teman berpengaruh sedang terhadap masalah belajarnya. Pengaruh sedang mengindikasikan bahwa pengaruh teman sebaya memberikan dampak positif dan negatif terhadap masalah belajar anak. Data ini diperkuat hasil wawancara yang mengungkapkan bahwa anak tersebut memiliki teman yang mendukung dan menghambatnya dalam belajar. Anak tersebut mengaku memiliki teman yang sering membantunya dalam belajar sehingga ia termotivasi untuk mengerjakan tugas-tugasnya. anak tersebut pun memiliki teman yang sering mengajaknya bermain. la merasa 'tidak enak' untuk menolak ajakan temannya untuk bermain karena alasan sering dibantu, sering bertemu, atau tidak ingin dimusuhi. Anak tersebut mengaku sering dijemput oleh temannya ke rumah untuk bermain di luar rumah sampai larut malam hingga ia ditegur oleh orang tuanya.

Menghabiskan banyak waktu dengan teman berdampak positif dan negatif terhadap prestasi anak. Dampak positif dapat diperoleh apabila anak berada di pada lingkungan pertemanan yang mendukung mereka untuk belajar atau mengerjakan tugas bersama. Dampak negatif terjadi apabila anak tidak dapat mengontrol waktu bermain hingga melupakan waktu belajar. Durasi bermain yang terlalu lama dengan teman menyebabkan anak lelah dan kesulitan mengatur waktu untuk belajar. Kesulitan anak dalam mengatur waktu belajar dapat menyebabkan masalah belajar pada anak karena anak tidak memiliki cukup waktu untuk belajar. Bangun (2008) menelaskan bahwa waktu belajar mempengaruhi prestasi anak. Semakin banyak waktu yang dimiliki anak untuk belajar, maka semakin tinggi prestasi yang dapat diperoleh anak.
Apabila anak berada pada lingkungan yang tidak mendukung belajar, maka anak tidak akan dapat menunjukkan prestasi yang maksimal. Hasil ini didukung penelitian Mujiastuti dan Ilyasir (2015) yang mengungkapkan bahwa anak yang memiliki persahabatan yang baik memiliki memiliki prestasi yang lebih baik dari pada anakanak yang tidak memiliki sahabat. Oleh karena itu kesadaran diri anak dalam memilih pergaulan dan peran orang tua dalam mengontrol pergaulan anak sangat dibutuhkan.

\section{Hubungan Anak dengan Orang Tua}

Rata-rata hubungan dengan orang tua berpengaruh positif terhadap masalah belajar yang dialami anak. Hasil ini sejalan dengan penelitian Bangun (2008) yang menyataan bahwa hubungan antara anak dengan orang tua mempengaruhi prestasi anak. Hubungan positif mengindikasikan adanya kepedulian orang tua terhadap pendidikan anak, penyediaan fasilitas belajar, pengawasan kegiatan belajar, penghargaan terhadap nilai yang diperoleh, serta keinginan orang tua untuk mengenal guru yang mengajar anaknya.

Apabila dianalisis secara individu, 2 dari $7 \quad(28,6 \%)$ anak superior menanggap hubungannya dengan orang tua memberi pengaruh sangat positif terhadap prestasinya. Data ini didukung hasil wawancara yang mengungkapkan bahwa motivasi dari orang tuanyalah yang membuat anak bersemangat dalam belajar. Orang tua mereka sering menanyakan keadaan dan nilai anak di sekolah, mengawasi anak dalam belajar, menyediakan fasilitas belajar, dan hubungan mereka dengan guru yang mengajar mereka. Orang tua pun memberi penghargaan pada anak ketika anak mampu meraih nilai diatas KKM (Kriterian Ketuntasan Minimal), dan memotivasi anak ketika anak mendapat nilai yang kurang dari KKM.

Sikap peduli orang tua terhadap pendidikan anak tersebut merupakan hubungan yang positif antara anak dengan orang tua yang membuat anak merasa diperhatikan dan mendapat dukungan dalam belajar. hasil ini didukung dengan 
penelitian Situmorang dan Latifah (2014) yang menyatakan bahwa dukungan sosial orang tua mempegaruhi prestasi anak. Anak merasa malu apabila mendapat nilai dibawah standar ketuntasan sehingga mereka termotivasi untuk terus meningkatkan prestasinya.

3 dari 7 (42,8\%) anak superior menganggap hubungan dengan orang tua berpengaruh positif terhadap masalah belajar yang dialami. Pengaruh positif mengindikasikan bahwa orang tua memberikan dukungan terhadap prestasi anak, namun masih terdapat aspek yang kurang diperhatikan oleh orang tua. Anakanak superior tersebut mengaku orag tuanya menanyakan hasil belajarnya, memberikan fasilitas belajar, dan memberi penghargaan berupa pujian atau motivasi terhadap nilai yang diperoleh anak. Walau demikian, orang tua jarang menanyakan kegiatan anak di sekolah, mengawasi anak dalam belajar, serta menanyakan hubungan anak dengan guru atau temannya.

Orang tua mereka sibuk bekerja. Orang tua tidak mengetahui kapan tes/ulangan di sekolah diadakan sehingga jarang mengarahkan untuk belajar. Orang tua tidak memberi tekanan atau tuntutan untuk anak dalam belajar. Orang tua pun tidak memberikan kewajiban dan memberikan kebebasan bagi anak untuk menentukan tujuannya. Salah satu anak mengaku hidup terpisah dengan orang tua sehingga jarang diawasi ketika belajar.

Kebebasan yang diberikan oleh orang tua dapat memberikan pengaruh positif dan negatif pada anak. Dampak positif yang timbul dari kebebasan yang diberikan orang tua adalah kemandirian anak dalam belajar dan memilih keputusan sendiri. Dampak negatif yang timbul dari kebebasan yang diberikan orang tua adalah tidak terpenuhinya kebutuhan anak superior. Bukan hanya kebutuhan materi saja, akan tetapi perhatian dalam proses belajar di rumah juga harus diperhatikan. Oktaviani dan widayat (2013) mengungkapkan bahwa anak berbakat memerlukan perhatian khusus dan metode penanganan yang berbeda dari anak-anak lainnya. Apabila tidak mendapat bimbingan, sangat besar kemungkinan anak tersebut mengalami depresi akibat tidak dapat mengendalikan pikirannya sendiri dan merasa tidak mendapat dukungan. Tidak menutup kemungkinan anak berkembang ke arah yang negatif.

2 dari 7 (28,6\%) anak superior menanggap hubungannya dengan orang tua memberi pengaruh sedang terhadap prestasinya. Pengaruh sedang mengindikasikan bahwa anak superior menganggap bahwa orang tuanya tidak memberikan dukungan penuh terhadap pendidikannya. Orang tua jarang menanyakan kagiatan belajar anak, mengawasi belajar anak, menanyakan hubungan anak dengan guru yang mengajar, serta memberi penghargaan terhadap prestasi anak. Data ini diperkuat hasil wawancara yang mengungkapkan bahwa kedua anak mengaku orang tuanya telah bercerai dan mereka sering berdebat dengan orang tuanya. Menurut kedua anak tersebut, orang tuanya sering mengucapkan kata-kata negatif ketika berdebat. Perdebatan disebabkan oleh berbagai faktor, diantaranya adalah prestasi belajar anak. Apabila anak mendapat nilai yang rendah, anak akan dicemooh sehinga mereka kehilangan motivasi untuk belajar.

Pengucapan katak-kata negatif, kurang perhatian, maupun kurang dukungan dari orang tua terhadap prestasi anak merupakan hubungan negatif yang berdampak pada kurangnya motivasi anak dalam belajar. Data ini sejalan dengan penelitian Bangun (2008) yang menyebutkan orang tua yang tidak memperhatikan pendidikan anaknya atau tidak peduli dengan kegiatan belajar anaknya, mengakibatkan anak tidak termotivasi dalam belajarnya. Anak menganggap bahwa belajarnya tidak didukung oleh orang tua sehingga anak akan merasa sia-sia dalam belajar.

\section{Hubungan Anak dengan Guru}

Rata-rata hubungan anak dengan orang tua berkategori berpengaruh positif terhadap masalah belajar yang dialami anak superior. Pengaruh tersebut diakibatkan karena guru merupakan 
pembimbing utama anak dalam belajar di sekolah. Hasil ini sejalan dengan berbagai penelitian (Angganing, 2011. Aritonag, 2006. Khumaero, 2017) yang menyatakan terdapat pengaruh antara cara mengajar guru terhadap prestasi anak. Aritonag (2006) yang mengungkapkan bahwa faktor utama yang menentukan minat dan motivasi belajar anak adalah guru.

Apabila dianalisis secara individu, 1 $(14,3 \%)$ anak menganggap hubungan dengan guru berpengaruh sangat positif terhadap masalah belajar yang dialaminya. Menurut anak tersebut, gurunya mengajar dengan jelas, mudah dipahami, dan menyenangkan. Guru-gurunya pun ramah dalam berkomunikasi dengan siswa. Data ini diperkuat hasil wawancara yang mengungkapkan bahwa anak tersebut merasa diperhatikan oleh salah seorang gurunya. Guru tersebut memberi saran secara personal ketika anak kesulitan berkonsentrasi dalam belajar karena memikirkan perdebatannya dengan orang tua. Anak tersebut mengaku termotivasi dengan saran yang diberikan gurunya sehingga ia semakin giat dalam belajar. Ini merupakan dampak positif hubungan antara anak dengan guru yang menyebabkan anak termotivasi dalam belajar. Anak menjadi aktif dalam proses pembelajaran di kelas dan merasa malu apabila tidak mengerjakan soal dengan benar. Hasil ini didukung penelitian Mulyasih dan Suryani (2016) mengungkapkan bahwa motivasi yang tinggi akan membuat anak menjadi lebih aktif dalam proses pembelajaran.

6 dari 7 (85,7\%) anak superior menganggap hubungan dengan guru berpengaruh positif terhadap masalah belajarnya. Anak mengaku senang belajar dengan guru dapat mengerti materi yang disampaikan guru. Rata-rata gurunya mengajar dengan jelas, mudah dimengerti, dan menyenangkan. Hasil ini diperkuat hasil wawancara yang mengungkapkan bahwa 5 anak superior memiliki guru idola yang membuat mereka termotivasi untuk belajar. Memiliki guru idola merupakan cerminan bahwa anak merasa bahwa guru dapat menjadi panutannya dalam belajar. Ini merupakan dampak positif hubungan antara anak dengan guru yang menyebabkan anak termotivasi dalam belajar. Hasil ini didukung pendapat Khumaero (2017) menggambarkan guru sebagai artis yang menjadi pusat perhatian di kelas. Oleh karenanya guru hendaknya mampu untuk menjaga perilaku agar siswa merasa nyaman untuk belajar, bertanya, atau berdiskusi dengannya.

Walau demikian 1 anak mengaku pernah mengalami masalah belajar karena tidak senang dengan salah seorang guru yang terlihat tidak ramah, dan kurang memotivasi dalam mengajar. Menurut anak, guru tersebut menjelaskan dengan volume suara yang terlalu rendah sehingga tidak terdengar jelas. Guru tersebut jarang memberikan apresiasi atau menginformasikan hasil dari tugas-tugas yang diberikan sehingga anak tidak mengetahui nilai yang diperolehnya. Media pembelajaran yang digunakan guru tidak beragam dan hanya terpaku pada buku sehingga pembelajaran menjadi kurang menyenangkan bagi anak.

Karakter yang kurang ramah, cara mengajar yang kurang memotivasi anak, serta kurang beragamnya fasilitas belajar yang digunakan patut menjadi perhatian guru. Karakter yang kurang ramah menyebabkan anak tidak leluasa untuk berdiskusi dengan guru. Hasil penelitian Handu dan Agustina (2011) membuktikan bahwa semakin tinggi motivasi anak, maka semakin tinggi prestasi yang mungkin diperoleh anak. Sejalan dengan pendapat Indrijati dan Hakim (2014), guru hendaknya dapat menyesuaikan cara mengajar yang digunakan dengan kebutuhan siswa. Hubungan yang baik antara guru dan anak akan memberi pengaruh positif berupa meningkatnya prestasi anak superior.

\section{SIMPULAN DAN SARAN Simpulan}

Berdasarkan hasil penelitian dan pembahasan, dapat disimpulkan bahwa terdapat pengaruh positif teman sebaya, orang tua, dan guru terhadap masalah belajar yang dialami anak superior di SMPN 4 Singaraja tahun ajaran 2017/2018 (anak- 
teman sebaya $75.87 \%$, anak-orang tua $62,91 \%$, anak-guru $74,60 \%$ ).

\section{Saran}

Anak, guru, dan orang tua hendaknya dapat menjalin hubungan komunikasi yang positif sehingga dapat menumbuhkan motivasi anak. Anak hendaknya dapat memilih pergaulan yang mendukung anak dalam belajar dan berprestasi. Apabila anak mengalami kesulitan dalam menolak ajakan teman yang menyebabkan masalah belajar pada anak, anak hendaknya mengomunikasikan kepada orang tua dan guru.

Orang tua hendaknya memperhatikan hubungan dengan anak dan menumbuhkan kepercayaan pada anak bahwa orang tua dapat membantu anak dalam menyenyelesaikan masalah belajar yang dialami anak. Orang tua juga hendaknya menggunakan kata-kata positif yang dapat menumbuhkan motivasi belajar anak.

Guru hendaknya dapat memberikan perhatian lebih pada anak-anak superior yang membutuhkan perhatian khusus. Guru disarankan agar dapat menyajikan pembelajaran yang merangsang minat belajar anak dan membantu anak dalam memahami pembelajaran. Guru juga diharapkan dapat berinteraksi denga anak agar dapat mendeteksi adanya masalah belajar yang dialami anak, sehingga anak yang mengalami masalah beajar dapat ditangani lebih dini.

\section{UCAPAN TERIMAKASIH}

Penulis menyadari bahwa artikel ini tidak dapat terselesaikan dengan baik apabila tanpa bantuan dan bimbingan berbagai pihak, oleh karena itu pada kempatan ini penulis mengucapkan terima kasih yang sebesar-besarnya kepada:

1. Dr. A. A. Istri Agung Rai Sudiatmika, M. $\mathrm{Pd}$ selaku dosen pembimbing utama dan Ketua Jurusan Pendidikan IPA yang telah memberikan bimbingan pada penyusunan artikel ini.

2. Ni Luh Pande Latria Devi, S.Pd., M. Pd selaku pembimbing pendamping yang telah memberikan bimbingan dan arahan pada penyusunan artikel ini.
3. Dr. Ni Made Pujani, M. Si selaku Koordinator Program Studi S1 Pendidikan IPA yang telah memberi dukungan dalam melakukan penelitian.

4. Putu Budiastana, S.Pd., M. Pd selaku Kepala SMPN 4 Singaraja yang telah memberi ijin melakukan penelitian di SMPN 4 Singaraja.

5. Luh Wilasih, S. Pd selaku guru mata pelajaran IPA di SMPN 4 Singaraja yang telah membantu dan memberikan informasi berkaitan dengan subjek penelitian.

6. 7 orang anak superior di SMPN 4 Singaraja yang telah bersedia menjadi subjek penelitian dan memberikan informasi dengan sebenar-benarnya.

7. Semua pihak yang tidak bisa disebutkan satu-persatu yang telah membantu pelaksanaan penelitian dan penyusunan laporan skripsi ini.

\section{DAFTAR PUSTAKA}

Ahmadi, A. 2004. Psikologi Pendidikan. Jakarta: Rineka Cipta

Angganing, P. (2011). Hubungan antara Gaya Mengajar Guru dan Sikap Peserta Didik dengan Prestasi Belajar Peserta Didik Kelas 5 di Kecamatan Wonogiri Kabupaten Wonogiri. Skripsi (tersedia dalam https://eprints.uns.ac. id/7164/1/214871011201103291.pdf).

Fakultas Keguruan IImu Pendidikan, Universitas Sebelas Maret (diakses tanggal 25 Desember 2017).

Aritonang, K. T. 2006. "Minat dan Motivasi dalam Meningkatkan Hasil Belajar Siswa". Pendidikan Penabur, nomor 10. Tersedia dalam https://s3.amazo naws.com/academia.edu.documents/35 904799/Hal._11-21_Minat_dan_motiv asi_belajar.pdf?AWSAccessKeyld=AKI AIWOWYYGZ2Y53UL3A\&Expires $=152$ 8233580\&Signature $=P \% 2 F 8 H C l o d G m h$ MblwErpWqpC3HyLg\%3D\&responsecontent-disposition=inline $\% 3 \mathrm{~B} \% 20 \mathrm{fi}$ lename\%3DMinat_dan_Motivasi_dalam Meningkatkan_Ha.pdf (diakses tanggal 25 Desember 2017). 
Bangun, D. 2008. "Hubungan Persepsi Siswa tentang Perhatian Orang Tua, Kelengkapan Fasilitas Belajar, Dan Penggunaan Waktu Belajar di Rumah Dengan Prestasi Belajar Ekonomi". Ekonomi \& Pendidikan, Volume 5, Nomor 1. Tersedia dalam https://journ al.uny.ac.id/index.php/jep/article/view/6 04/461 (diakses tanggal 18 Februari 2018).

Blaas, S. 2014. "The Relationship Between Social-Emotional Difficulties and Underachievement of Gifted Student". Australian Journal of Guidance and Counselling Volume 24, Issue 2. Tersedia dalam https://www. cambridg e.org/core/servic es/aop-cambridgecore/content/view/65518F6

A8D5AF91B99964EF056E18A0A/S103 7291114000016a.pdf/relationship_betw een_socialemotional_difficulties_and_u nderachievement_of_gifted_students.pd $f$ (diakses tanggal 15 Desember 2016).

Ernawati, N. L. M. D., IW. Sadia, I.B. Putu Arnyana. 2014. "Pengaruh Pola Asuh Orang Tua, Interaksi Teman Sebaya dan Kecerdasan Emosional Terhadap Hasil Belajar IPA Pada Siswa Kelas VIII SMP Negeri Se-Kecamatan Mengawi". Ejournal Program Pascasarjana Universitas Pendidikan Ganesha, 4. Tersedia http://119.252.161.254/ejournal/index.php/ jurnal_ipa /article/down load/1079/827 (diakses tanggal 23 Maret 2018).

Gregory, R. J. 2010. Tes Psikologi. Sejarah, Prinsip, dan Aplikasinya. Jakarta: Erlangga

Huroniah, F. 2013. "Mengenali Anak Berkesulitan Belajar (Tinjauan Psikologi Terhadap Anak "Gifted")". Ejournal lain Jember, Volume 8, Nomor 1. Tersedia dalam http://ejourn al.iainjember.ac.id/index.php/alfitrah/ article/download/365/346 (diakses tanggal 01 Desember 2017).

Kementrian Pendidikan dan Kebudayaan. 2015. "Survei International PISA". Tersedia dalam http://litbang.kemendik bud.go.id/index.php/survei-internationl pisa/tentang-pisa. (diakses tanggal 5 Desember 2017)

Kharisma, N. dan L. Lutifah. 2015. "Pengaruh Motivasi, Prestasi Belajar, Status Sosial Ekonomi Orang Tua dan Lingkungan Teman Sebaya terhadap Minat Melanjutkan Pendidikan ke Perguruan Tinggi Pada Siswa Kelas Xii Kompetensi Keahlian Akuntansi Di Smk Negeri Sekota Semarang Tahun Ajaran 2014/2015". Economic Education Analysis Journal, Volume 4, Nomor 3. Tersedia dalam https://journ al.unnes.ac.id/sju/index.php/eeaj/article/ view/8524 (diakses tanggal 01 Desember 2017).

Khumaero, A. L. dan S. Arief. 2017. "Pengaruh Gaya Mengajar Guru, Disiplin Belajar, dan Teman Sebaya Terhadap Prestasi Belajar". Economic Education Analysis Journal, Volume 4, Nomor 3. Tersedia dalam https://journ al.unnes.ac.id/sju/index.php/eeaj/article/ view/20281 (diakses tanggal 20 Desember 2017).

Kusuma, Y. P. dan Muhsin. 2016. "Pengaruh Motivasi Belajar, Lingkungan Teman Sebaya, dan Bahan Ajar Terhadap Kesiapan Belajar". Economic Education Analysis Journal, Volume 5, Nomor 2. Tersedia dalam https://journal.unnes.

ac.id/sju/index.php/eeaj/article/view/136 62 (diakses tanggal 03 Desember 2017).

Mujiastuti, A. I. C. dan F. llyasir. 2015. "Pengaruh Pertemanan Sebaya terhadap Prestasi Belajar Pendidikan Agama Islam Siswa Kelas Xi Sma Negeri 1 Sewon, Bantul Tahun Pelajaran 2013/2014". Literasi, Volume 6, Nomor 1. Tersedia dalam http://ejournal.almaata.ac.id/index.php/L ITERASI/article/viewFile/185/182 (diakses tanggal 10 Desember 2017).

Mulyasih, P. S. dan N. Suryani. 2016. "Pengaruh Disiplin Belajar, Lingkungan Keluarga, dan Motivasi Belajar Terhadap Prestasi Belajar Mata 
Pelajaran Pengantar Administrasi". Economic Education Analysis Journal Volume 5 Nomor 2. Tersedia dalam https://journal.unnes.ac.id/sju/index.php/ eeaj/article/view/13664 (diakses tanggal 19 Desember 2017).

Oktaviani, L. P. dan I. W. Widayat. 2013. "Studi Deskriptif Gaya Belajar Siswa di kelas Akselerasi”. Psikologi Kepribadian dan Sosial, Volume 02, Nomor 03. Tersedia dalam http://journ al.unair.ac.id/download-fullpapersjpksd 7f00bb1732full.pdf (diakses tanggal 15 Desember 2017).

Rifa'i, A. dan C. T. Anni. 2012. Psikologi Pendidikan. Semarang: UNNES Press.

Santrock, J. W. 2008. Perkembangan Anak - Jilid 1 (edisi kesebelas). Jakarta: Erlangga

Santrock, J. W. 2009. Piskologi Pendidikan. Jakarta: Salemba Humanika.

Slameto. (2010). Belajar dan Faktor-faktor yang Mempengaruhinya. Jakarta: PT Rineka Cipta
Song, K. H. 2014. "Domain Thought in Gifted Students and Gifted Students with Learning Disabilities". Gifted/Talented Education, Volume 24 Nomor 5. Tersedia dalam http://www. ndsl.kr/soc_img/society/ksg/OJHHBM/2 014/v24n5/OJHHBM_2014_v24n5_851. pdf (diakses tanggal $1 \overline{4}$ Desember 2017).

Sukardi, D. K. 1997. Analisis Tes Psikologis. Jakarta: Rineka Cipta.

Thompson, J. 2010. Memahami Anak Berkebutuhan Khusus. Jakarta: Erlanga

Tirtaraharja, U., dan L. Sulo. (2010). Pengantar Pendidikan. Jakarta: Rineka Cipta.

Undang-undang Nomor 20 Tahun 2003 Tentang Sistem Pendidikan Nasional. 2003. Jakarta: Depdiknas

Uno, H. B. 2008. Teori Motivasi dan Pengukuran: Analisis di Bidang Pendidikan. Jakarta: Bumi Aksara.

Zubaidi, A. 2009. Tes Intelegensi. Jakarta: Mitra Wacana Media. 